\title{
Liquefied natural gas road transport: a simulation study in Mato Grosso, Brazil
}

\author{
Transporte rodoviário de gás natural liquefeito: um estudo de simulação \\ em Mato Grosso, Brasil
}

\section{Dorival Suriano dos Santos Júnior ${ }^{1}$, Anna Luisa Abreu Netto ${ }^{2}$, Drielli Peyerl ${ }^{3}$, Denis Martins Fraga ${ }^{4}$, Edmilson Moutinho dos Santos ${ }^{5}$}

\author{
1University of São Paulo, São Paulo - Brazil, dorival.santos@usp.br \\ 2University of São Paulo, São Paulo - Brazil, annaluisanetto@usp.br \\ 3University of São Paulo, São Paulo - Brazil, dpeyerl@usp.br \\ ${ }^{4}$ University of São Paulo, São Paulo - Brazil, fraga.denis@gmail.com \\ 5University of São Paulo, São Paulo - Brazil, edsantos@iee.usp.br
}

\section{Recebido:}

5 de setembro de 2020

Aceito para publicação:

19 de julho de 2021

Publicado:

9 de dezembro de 2021

Editor de área:

Renato da Silva Lima

\section{Keywords:}

Road transport.

Energy transport.

Liquefied Natural Gas.

Brazil.

\section{Palavras-chaves:}

Transporte rodoviário.

Transporte de energia.

Gás Natural Liquefeito.

Brasil.

DOI:10.14295/transportes.v29i4.2450

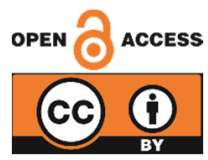

\begin{abstract}
The aim of this article is to evaluate the viability of transporting Liquified Natural Gas (LNG) by truck in the Mato Grosso (MT) state, Brazil, comparing the costs of substituting other energy sources for the Bolivian Natural Gas (NG) and estimating the potential available market in the five mesoregions of the state. The simulation results show a potential NG market of $2.1 \mathrm{MMm} 3 /$ day at a competitive cost compared to the assessed fuels in the economic sectors evaluated in the MT state. LNG transported by road has shown to be more advantageous than electric energy and diesel oil. On the other hand, fuel oil costs were slightly lower than NG costs. This simulation can serve as inspiration to extend the use of small-scale LNG by road in states or countries with similar characteristics, especially those with the possibility of the constant supply of NG and limited pipeline network.
\end{abstract}

\section{RESUMO}

O objetivo deste artigo é avaliar a viabilidade do transporte de Gás Natural Liquefeito (GNL) por caminhão no estado de Mato Grosso (MT), Brasil, comparando os custos de substituição de outras fontes energéticas para o Gás Natural (GN) boliviano e estimando o potencial mercado disponível nas cinco mesoregiões do estado. Os resultados do estudo mostram que existe um mercado potencial de GN de 2,1 MMm3/dia a um custo competitivo em comparação com os combustíveis avaliados. O GNL transportado por estrada demonstrou ser mais vantajoso do que energia elétrica e diesel. Por outro lado, os custos do óleo combustível foram ligeiramente mais baixos do que os custos do GN. Esta simulação pode servir de inspiração para aumentar a utilização do GNL em pequena escala por estrada em estados ou países com características semelhantes, especialmente aqueles com a possibilidade de fornecimento constante de GN e rede limitada de gasodutos.

\section{INTRODUCTION}

Natural Gas (NG) is considered cleaner and an environmentally more acceptable power generation option than other fossil fuels mainly due to lower greenhouse gas emissions (Hekkert et al., 2005; Hondo, 2005; Kumar et al., 2011). For this reason, many authors have studied NG as a "bridge fuel" or "transition fuel" to low carbon energy sources (Cathles, 2012; Howarth, 2014; Levi, 2013). In some countries, mainly in developing countries as Brazil, NG has been considered an energy security resource, which would allow countries to gradually change 
their energy mix with the predominance of fossil sources (including oil and coal) to a so-called more sustainable mix through the participation of renewable energy sources (Alexopoulos, 2017; Colombo et al., 2016; Santos et al., 2007; Zhang et al., 2016).

Also, NG has been considered a future sustainable energy source to decarbonise some economic sectors (Safari et al., 2019). The low cost, high availability and low carbon emissions of natural gas make this resource one of the main options for sustainable economic growth (Alam et al., 2017). Therefore, it is important to delve deeper into how this NG expansion and changes in the sectors could happen in Brazil.

In Brazil, the importance of NG in its energy mix has been growing exponentially in the last 30 years. In 2018, it corresponded to $13 \%$ of all primary energy sources available in the country, behind only oil products and sugarcane products (EPE, 2019). In 2019, the sector that consumed more NG in Brazil was the industry (28\%), then there was the consumption in the oil production wells reinjection process (25\%) and thirdly the thermoelectric plants (20\%) (MME, 2019a). NG is presently considered an important energy alternative for the automotive sector and households (Cavalcante, 2004; Teixeira, 2015). In the next years, there is a trend of increasing NG consumption in Brazil due to measures that make the NG market open, dynamic and competitive, a governmental program called "New Gas Market" launched in 2019 (MME, 2019b).

One of the main milestones in the expansion of natural gas in Brazil was the agreement, in 1996, for the construction of the Bolivia-Brazil pipeline (GASBOL), whose construction was completed in 1998, with the maximum capacity of transporting 30mcm/day (García Kerdan et al., 2019). In 2018, NG imported from Bolivia was responsible for about 22,6\% of NG offer in the Brazilian market (ANP, 2019). However, given the expectation of an increase in the Brazilian NG production from the fields in the Pre-salt polygon (Azevedo Filho et al., 2019; Cezário et al., 2015; Costa et al., 2016), there are still uncertainties regarding the NG volume coming from Bolivia that will be necessary to supply the South and Southeast of the country in the next years. Therefore, it is needed to evaluate alternatives for using Bolivian NG and consider new markets.

In order to ponder about potential markets for Bolivian NG, it is necessary to consider that access to many consumption points requires less conventional logistic solutions, such as smallscale production of Liquefied Natural Gas (LNG) and transport by road. Within this scenario, the Brazilian state of Mato Grosso (MT) can be a potential market for some reasons: the state borders Bolivia; there is a gas pipeline that connects Bolivia to the state capital (Cuiabá city), which is idle. Due to the lack of a pipeline distribution network within the state of MT, there is an opportunity to transport LNG produced on a small-scale by road for the interiorization of NG in the state.

Within this strategic perspective, this article aims to evaluate the viability of transporting LNG by truck in the MT state, Brazil, comparing the costs of substituting other energy sources for the Bolivian NG and estimating the potential available market in the five mesoregions of the state. The methodology approach is based on the cost estimation model, which quantifies all the logistic costs involved in the LNG transportation through trucks (Fraga, 2019).

The paper is organized into the following sections. Section 2 discusses the transport by truck of small-scale LNG in a wider context and the socio-economic features and energy consumption in MT. Section 3 describes the methodology approach, and Section 4 presents the results, analyzing the possibility of supplying the state of MT with Bolivian NG. Finally, Section 5 gives the conclusions of this work. 


\section{BACKGROUND}

\subsection{Transport by truck of small-scale Liquefied Natural Gas}

NG can be liquefied if cooled to a temperature of $163^{\circ}$ Celsius negative and, when this happens, the volume of $\mathrm{NG}$, compared to that in normal conditions of pressure and temperature, is reduced by approximately 600 times (Bittante et al., 2018; Kumar et al., 2011). This reduction in storage volume and compression, maintaining the NG energy density, allows the LNG transportation to be advantageous when long distances between the producer and the consumer are involved and when there are absences of pipelines available for NG transportation (Bittante et al., 2018). In addition, LNG can be transported by ships (Mokhatab et al., 2014), trains (Liaw, 2019) and trucks (Mokhatab et al., 2014).

Following the global growth trend of the NG industry, LNG has also gained important space, helping different regions of the globe to have access to NG and helping the gas industry integration (BP, 2019). The main end-uses of LNG are heavy-duty vehicles; special trucks of haulage companies; marine transportation; large logistic operators; generation of electricity in thermal power plants; and industrial consumption in regions disconnected from the gas pipeline network (Biscardini et al., 2017; dos Santos, 2002).

Small-scale Liquefied Natural Gas (SSLNG) is characterized according to the production capacity of the liquefaction and regasification plants (IGU, 2015). To be considered as SSLNG, this capacity corresponds to the range from 0.1 MTPA to 1 MTPA, which corresponds to 0.32 to 3.3 $\mathrm{MMm}^{3}$ /day (IGU, 2015). The LNG integrated logistics chain consists of the liquefaction, transportation, storage and regasification stages to reach the point of consumption.

To maintain its temperature at $-163^{\circ}$ Celsius during transportation by truck, LNG is generally transported in two types of tanks, called conventional tank and container. The main differences are related to the volume capacity to be transported $\left(20 \mathrm{~m}^{3}\right.$ to $60 \mathrm{~m}^{3}$ in the first type and $32 \mathrm{~m}^{3}$ in the second). Furthermore, in the container type, it is possible to transport and interconnect with different types of transportation modes, such as rail, ship and road (Fraga et al., 2017).

The interconnection of different means of transport is advantageous in cases where LNG transport between a liquefaction plant and the end user can only be achieved via truck and/or rail and/or waterway. It is also possible to design a cabotage ship/coastal transport from an LNG terminal to different ports that access consumers or consumption routes (Alves et al., 2005). In other words, the choice between conventional tank and container depends on the logistical limitations of LNG circulation of each project and each location (Alves et al., 2005).

\subsection{Socio-economic characteristics and energy consumption in Mato Grosso state}

The state of MT is in the Midwest region of Brazil. It borders Bolivia and shares with this country the characteristic of being landlocked and not using the sea to drain its internal production (mainly agricultural) and to receive the required imported inputs, including energy (IBGE, 2019).

MT had an estimated population of 3.5 million people in 2019 and a territory of $903,000 \mathrm{~km}^{2}$, the third-largest Brazilian state (IBGE, 2019). The agricultural sector represents the main engine of the MT economy, being responsible for approximately $51 \%$ of the state's GDP (IMEA, 2019). Regarding the industry, the main segments in the state are food manufacturing, mainly beef processing, and soybean oil and derivatives (Matsubara, 2016). 
Based on the state's socio-economic and geographic characteristics, MT is divided into five mesoregions. A brief description of the main socio-economic characteristics of these five mesoregions is described in Table 1.

Table 1 - MT State Mesoregion Features

\begin{tabular}{|c|c|c|c|}
\hline Mesoregion & Population (mil) & Municipalities & Main Features \\
\hline North & 1,100 & 55 & $\begin{array}{l}\text { - The largest and most important economic region of MT State (responsible for } \\
36 \% \text { of MT GDP); } \\
\text { - The largest MT State grain production (of the ten largest soy producing } \\
\text { municipalities in Brazil, the first four are located in this mesoregion: } \\
\text { Sorriso, Sapezal, Campo Novo do Parecis and Nova Mutum; } \\
\text { - Main agroindustrial groups: Amaggi and Scheffer }\end{array}$ \\
\hline South Central & 1,000 & 17 & $\begin{array}{l}\text { - It hosts the two largest cities of the State: Cuiabá (capital) and Várzea Grande; } \\
\text { - Main agribusiness groups: Coke Comp. and AmBev beverage industries; } \\
\text { Votorantim cement industry and BRF food group }\end{array}$ \\
\hline Southeast & 490 & 22 & $\begin{array}{l}\text { - Local economic activity stands out for its agricultural and industrial, } \\
\text { highlighting Rondonópolis, an agro-industrial hub, which also has one of the } \\
\text { State's three rail terminals. } \\
\text { - Main agroindustrial groups: Bunge food multinational, Petrópolis } \\
\text { brewery and the agroindustrial group, Amaggi }\end{array}$ \\
\hline Southwest & 306 & 22 & $\begin{array}{l}\text { - Highlight economic activity: extensive beef and dairy farming, agriculture and } \\
\text { mining } \\
\text { - Highlight in the extraction of gold diamonds from Brazil ( } 87 \% \text { of the national } \\
\text { production occurs in MT, and the extraction occurs mainly in this State region); } \\
\text { - Main business groups: JBS refrigerator, the Marfrig agricultural group and the } \\
\text { mining company Apoema. }\end{array}$ \\
\hline Northeast & 275 & 25 & $\begin{array}{l}\text { - It is considered the most lacking in socio-economic infrastructure; } \\
\text { - Municipalities separately distributed. } \\
\text { - Main economic activities in the region are the beef and pork processing } \\
\text { sectors, including the presence of the JBS refrigeration group. }\end{array}$ \\
\hline
\end{tabular}

The total primary energy consumption of the state is equivalent to 5.0 MMtoe, corresponding to about $2 \%$ of the total primary energy consumption in Brazil (EPE, 2019). In 2017, the main energy sources consumed in the state of MT were: refined oil products (57\%), biomass products $(28 \%)$ and electricity (15\%) (NIEPE, 2017). In the refined oil products category, diesel oil was the main fuel of this group (76\%). The remaining $24 \%$ are composed of fuel oil, aviation kerosene, LPG, gasoline and petroleum coke (NIEPE, 2017).

NG had a minimal share in the state's total demand in 2016, with only $0.05 \%$ of all energy consumption in the state. All the NG consumed in MT was imported from Bolivia through the Lateral-Cuiabá gas pipeline and served mainly the industrial, transportation and electric power generation sectors (NIEPE, 2017). The expansion of the NG share in the energy consumption can be seen as an opportunity to diversify the consumption mix and improve the state's energy security, as well as a motivator for attracting investments for the expansion of the gas industry in the region.

Regarding final energy uses, the transport sector is the largest energy consumer in MT, corresponding to $48 \%$ of total demand in 2017 . This demonstrates the logistic challenges associated with a new economic frontier marked by large distances, a very dispersed population and economic activity. The agricultural, industrial and residential sectors appear as the second (15\%), third (13\%) and fourth (9\%) largest consumers in the state (NIEPE, 2017). Energy consumption was also analysed according to the consumption per mesoregions of MT (Figure 1). 


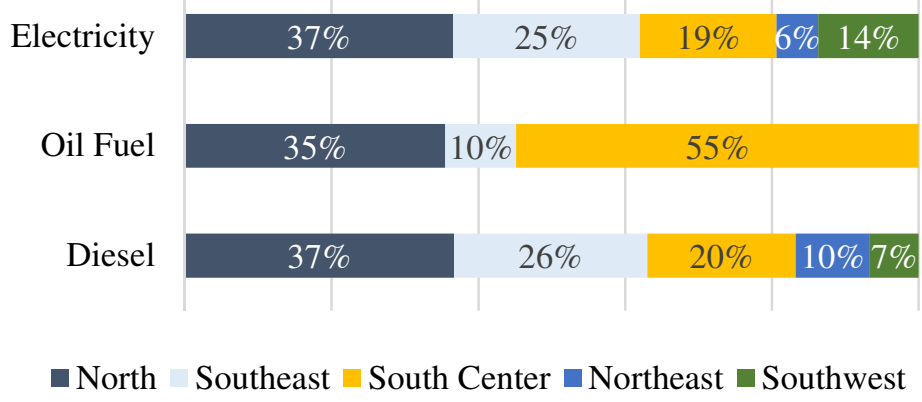

Figure 1. MT Energy Consumption per mesoregion

According to Figure 1, the North and Southeast mesoregions are the most energy-consuming regions of the MT state. The North region is the largest grain productor and the region's most economically important of the state, responsible for $36 \%$ of total MT GDP. The Southeast mesoregion has strong industrial and agricultural sectors, using $25 \%$ of all electricity and diesel consumed in the state of MT. The South central is the third energy consumer, accounting for $55 \%$ of state oil consumption. At last, the Northeast and Southwest are the lowest energy consumers of the MT state.

\section{METHODOLOGY}

In order to assess the feasibility of using road transportation for the supply of LNG in a given region, this article will carry out a modelling and a simulation, in which it will be examined the possibility of supplying the state of MT with Bolivian NG. This logistic solution was considered due to the availability of the Lateral-Cuiabá pipeline and is consistent with the energy supply and demand characteristics of the MT state. This simulation evaluates a potential available market in the five mesoregions of the MT state. Furthermore, given the absence of gas pipelines for the transportation and distribution of NG in the other regions of the state, besides Cuiabá, the study considers the liquefaction of Bolivian NG in Cuiabá and its transport to the other regions by truck in liquefied form.

For that, a cost estimation model, developed by Fraga (2019), was used, which quantifies, in the USD/MMBtu unit, all the logistic costs involved in the LNG transportation through trucks. The costs obtained for the LNG supply chain were compared with the costs of fuel oil, diesel oil and electricity, consumed in the agricultural, industrial and transport sectors in the state of MT in 2018. The energy sources and economic activities were selected based on the relevance of these sectors and the types of fuels shown in the energy balance of the MT state. The simulation study had the following steps:

- Step 1: Collect primary data

- Step 2: Calculate routes from liquefaction plant to consumer point

- Step 3: Calculate potential energy substitution

- Step 4: Design and calculate the cost of liquefaction, storage and regasification plants

- Step 5: Build Total Cost NG+SSLNG (USD/MMBTU)

- Step 6: Calculate the differences between the cost obtained in (5) and Diesel, Fuel Oil and Electricity cost

- Step 7: Georeference the results 
For the first step, data were collected on: energy consumption of the agricultural, industrial and transport sectors in the five mesoregions of MT; consumer market in the five mesoregions to understand in which cities the main agricultural and industrial consuming centers of fuel oil, diesel and electricity are located; average costs practiced in the state of MT regarding fuel oil, diesel and electricity, for the economic sectors studied.

In the second step, the centroids of each state mesoregion were defined based on the location of the geographical center of each of the five mesoregions and the agricultural/industrial clusters identified. LNG transport routes to these points were calculated using the road mesh available in Openstreetmap, allowing delimiting the roads only on paved roads (Openstreetmap, 2018). The ArcGIS (Geographic Information System) tool was used to calculate the routes and points of the centroids of each mesoregion. This calculation is important for the dimensioning of the quantity of trucks, tanks demanded for the delivery of LNG and all other logistic costs associated with the delivery. As a point of origin of LNG transportation, the city of Cuiabá was considered, where there is already a city-gate located at the end point of the Lateral-Cuiabá Gas Pipeline. In the economic model, it was considered the construction of a liquefaction plant near this city-gate, and it was assumed that each truck supplied with LNG would depart from this plant to the centers of the five mesoregions.

In the third step, the calculation of the potential volume of substitution of fuel oil, diesel oil and electricity by NG was carried out from the methods described by Gallo (2018) and Strapasson (2004).

Concerning the substitution potential of electricity by NG, obtained in Joules ( $P$ ot $N$ Gjsel), the equation is described as the product of total electricity consumption in Joules ( $C$ o $n$ el), by the substitution percentage of a certain sector (\% $s u b s$ ) and by the electricity yield (Yel), divided by NG yield ( $\mathrm{Y}_{\mathrm{NG}}$ ) (Gallo, 2018). This relationship is presented in Equation 1.

$$
\operatorname{PotNG}_{\mathrm{jsel}}=\frac{\operatorname{con}_{\mathrm{el}} * \% s u b_{\mathrm{s}} * \mathrm{Y}_{\mathrm{el}}}{\mathrm{Y}_{\mathrm{NG}}}
$$

Through Equation 1, it is possible to convert the given substitution potential from Joules to the unit normal cubic meters $\left(0^{\circ} \mathrm{C}\right.$ and $\left.1 \mathrm{~atm}\right)$ per day ( $P$ ot $\left.G N \mathrm{~m}^{3} \mathrm{~s}\right)$ by applying a conversion

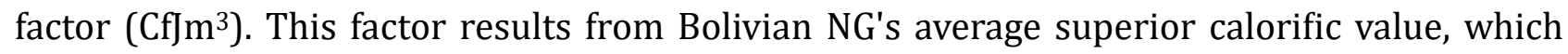
corresponds to $40 \mathrm{MJ} / \mathrm{m}^{3}$. The factor of 1.092 converts the potential of normal cubic meters to base condition $\left(20^{\circ} \mathrm{C}\right.$ and $\left.1 \mathrm{~atm}\right)$, divided by the number of days of the year, resulting in the NG replacement potential in $\mathrm{m}^{3} /$ day, as shown in Equation 2.

$$
\operatorname{PotNG} \mathrm{G}_{\mathrm{m} 3 \mathrm{~s}}=\frac{\operatorname{PotNG}_{\mathrm{jsel}} / 10^{6} * 1.092}{\mathrm{Cf}_{\mathrm{Jm} 3} * 365}
$$

Regarding fuel oil and diesel oil, the calculation of the NG substitution potential for a certain sector ( $P$ ot $G N$ jso), represented by Equation 3, is obtained by the product of total fuel oil /diesel consumption ( $C$ o $n$ O) and its yields (YO), divided by NG yield (YNG). In order to obtain the potential value of substitution in the unit $\mathrm{m} 3 /$ day, Equation 4, obtained in a similar way to Equation 2, is adopted.

$$
\begin{gathered}
\operatorname{PotNG}_{\mathrm{jso}}=\frac{\operatorname{Con}_{\mathrm{O}} * \mathrm{Y}_{\mathrm{O}}}{\mathrm{Y}_{\mathrm{NG}}} \\
\operatorname{PotNG} \mathrm{m}_{\mathrm{m} 3 \mathrm{~s}}=\frac{\operatorname{PotNG}_{\mathrm{jso}} / 10^{6} * 1.092}{\mathrm{Cf}_{\mathrm{Jm} 3} * 365}
\end{gathered}
$$

Since Equations 1 and 3 require energy consumption in the Joule (J) unit as input data, the following conversion factors related to the total consumption of electricity, diesel oil and fuel oil are used: $1 \mathrm{MWh}=3,600 \mathrm{MJ}$; Heat output diesel oil: $36 \mathrm{MJ} / \mathrm{liter}$; Heat output fuel oil: $42 \mathrm{MJ} /$ liter. 
Regarding the percentage of substitution of electricity and diesel oil by NG in the industry and the agricultural activity, the values suggested by Gallo (2018), and Strapassono (2004) were adopted, which establish the substitution percentages for different types of industry and for the agricultural activity. In the present simulation study, the average percentage of the substitution applied was $28 \%$. For the agriculture sector, the authors consider a value of $60 \%$ as a percentage of substitution of electricity and diesel oil for NG. Regarding fuel oil, the percentage of substitution by NG has been set at $100 \%$ in the agricultural and industrial sectors. The thermal end uses are compatible and susceptible of substitution by NG most of the time. On the other hand, concerning the percent substitution of diesel oil by NG in the transport sector, Mouette et al. (2019) suggest $10 \%$ as the volume of diesel oil to be substituted by NG in transport vehicles (Mouette et al., 2019). The values of energy sources considered were also adopted, as suggested by Gallo (2018) and Strapasson (2004). These values were incorporated into the quantitative cost estimation model for obtaining the NG potential demand in the state of MT for the economic sectors considered. The energy performance of the energy sources studied are: Fuel Oil (70\%); Diesel (70\%), Electricity (78\%) and Natural Gas (71\%).

In this fourth step, the economic model for cost estimation is used to determine the costs, per energy unit (USD/MMBtu), related to the LNG logistics chain on a small-scale, i.e., liquefaction, modal road movement, storage and regasification of the potential volumes of NG estimated above. Therefore, such costs refer to the logistics of transformation and transportation of NG, via LNG, from Cuiabá's city gate to the centroid points of each mesoregion in the state of MT.

For the economic model, to calculate the final LNG transportation costs for each of the 5 MT mesoregions, it is necessary to calculate the inputs, which are formed by the costs of Capital Expenditure (CAPEX) and Operational Expenditure (OPEX) of NG, Liquefaction, Transport and Storage/Regas and by the expected Energy consumption, considering the MT Energy balance and the potential substitution volume of NG. The model output is the Energy Cost (in USD/MMBTU).

The results of the NG logistic cost were obtained considering a time horizon of 30 years, equivalent to the average concession time of NG distributors in Brazil. In order to compare all costs at present value, a minimum attractiveness rate corresponding to $10 \%$ p.a. represents the weighted average cost of capital adequate to the basic interest rate in the country of $6.5 \%$ p.a (BCB, n.d.).

In the fifth step, the cost of Bolivian NG and the taxes related to the movement of products must be added to the total logistic costs. Using the methodology proposed by Fraga (2019), the calculation of the total cost of Small-scale LNG movement is represented by Equation (5), which is defined by the sum of the cost of LNG moved between Bolivia and the LNG delivery point in Cuiabá, with the cost of the Small-scale LNG chain and with the taxes applied to the transportation of goods.

$$
\operatorname{lng} T C=n g C+\text { liqTC }+ \text { transTC }+ \text { storegTC }+ \text { taxes }
$$

were:

lngTC: total LNG handling costs

ngC: cost of Bolivian NG (molecule +transport) to the city of Cuiabá, via the Lateral-Cuiabá gas pipeline

liqTC: $\quad$ cost of liquefying NG

transTC: cost of LNG transport by road 
storegTC: cost of LNG storage and regasification

Taxes: Program for Social Integration (PIS) (1.65\%), Contribution to Social Security Financing (COFINS) (7.6\%) and Tax on Goods and Services (ICMS) (15\%).

Finally, the steps 6 and 7 are performed with the data obtained in the previous steps.

\subsection{Primary Data Collection}

The primary data collection on energy consumption of the five MT mesoregions' agricultural, industrial and transport sectors was obtained from NIEPE (2017). Tables 2 shows the energy consumption data for MT for each type of fuel analyzed in each of the five mesoregions and a percentage comparison with the total energy consumption in MT.

Table 2 - MT State Diesel, Fuel Oil and Electricity Consumption for agriculture, industry and transport

\begin{tabular}{|c|c|c|c|c|c|c|c|c|c|c|c|}
\hline \multicolumn{12}{|c|}{ MT State Diesel Consumption for agriculture, industry and transport (Diesel/'000 m³) } \\
\hline & $\begin{array}{c}\text { Total MT } \\
\text { state }\end{array}$ & North & $\begin{array}{c}\% / \text { total } \\
\text { MT }\end{array}$ & $\begin{array}{l}\text { South } \\
\text { Central }\end{array}$ & $\begin{array}{c}\text { \%/total } \\
\text { MT }\end{array}$ & Southeast & $\begin{array}{c}\text { \%/total } \\
\text { MT }\end{array}$ & Southwest & $\begin{array}{c}\text { \%/total } \\
\text { MT }\end{array}$ & Northeast & $\begin{array}{c}\text { \%/total } \\
\text { MT }\end{array}$ \\
\hline Agriculture & 726,1 & 384,8 & $53,0 \%$ & 36,0 & $5 \%$ & 134,5 & $18,5 \%$ & 50,8 & $7,0 \%$ & 120,0 & $16,5 \%$ \\
\hline Transport & 1872,8 & 570,0 & $30,4 \%$ & 481,8 & $26 \%$ & 559,2 & $29,9 \%$ & 113,7 & $6,1 \%$ & 148,1 & $7,9 \%$ \\
\hline Industry & 60,1 & 19,9 & $33,1 \%$ & 20,3 & $34 \%$ & 6,6 & $11,0 \%$ & 12,8 & $21,3 \%$ & 0,5 & $0,8 \%$ \\
\hline Total & 2659,0 & 974,7 & $36,7 \%$ & 538,1 & $20 \%$ & 700,3 & $26,3 \%$ & 177,3 & $6,7 \%$ & 268,6 & $10,1 \%$ \\
\hline \multicolumn{12}{|c|}{ MT State Fuel Oil Consumption for agriculture and industry (Fuel Oil/'000 m³) } \\
\hline & $\begin{array}{l}\text { Total MT } \\
\text { state }\end{array}$ & North & $\begin{array}{c}\text { \%/total } \\
\text { MT }\end{array}$ & $\begin{array}{l}\text { South } \\
\text { Central }\end{array}$ & $\begin{array}{c}\text { \%/total } \\
\text { MT }\end{array}$ & Southeast & $\begin{array}{c}\text { \%/total } \\
\text { MT }\end{array}$ & Southwest & $\begin{array}{c}\text { \%/total } \\
\text { MT }\end{array}$ & Northeast & $\begin{array}{c}\% / \text { total } \\
\text { MT }\end{array}$ \\
\hline Agriculture & 1,4 & 1,1 & $78,6 \%$ & 0,0 & $0,0 \%$ & 0,3 & $21,4 \%$ & 0,0 & $0,0 \%$ & 0,0 & $0,0 \%$ \\
\hline Industry & 1,7 & 0,0 & $0,0 \%$ & 1,7 & $100,0 \%$ & 0,0 & $0,0 \%$ & 0,0 & $0,0 \%$ & 0,0 & $0,0 \%$ \\
\hline Total & 1,1 & 1,1 & $35,5 \%$ & 1,7 & $54,8 \%$ & 0,3 & $9,7 \%$ & 0,0 & $0,0 \%$ & 0,0 & $0,0 \%$ \\
\hline \multicolumn{12}{|c|}{ MT State Fuel Electricity for agriculture and industry (Electricity/GWh) } \\
\hline & $\begin{array}{c}\text { Total MT } \\
\text { state }\end{array}$ & North & $\begin{array}{c}\text { \%/total } \\
\text { MT }\end{array}$ & $\begin{array}{l}\text { South } \\
\text { Central }\end{array}$ & $\begin{array}{c}\text { \%/total } \\
\text { MT }\end{array}$ & Southeast & $\begin{array}{c}\text { \%/total } \\
\text { MT }\end{array}$ & Southwest & $\begin{array}{c}\text { \%/total } \\
\text { MT }\end{array}$ & Northeast & $\begin{array}{c}\text { \%/total } \\
\text { MT }\end{array}$ \\
\hline Agriculture & 937,6 & 462,8 & $49,4 \%$ & 73,0 & $7,8 \%$ & 227,4 & $24,3 \%$ & 89,5 & $9,5 \%$ & 84,9 & $9,1 \%$ \\
\hline Industry & 2377,5 & 748,8 & $31,5 \%$ & 545,1 & $22,9 \%$ & 616,3 & $25,9 \%$ & 365,0 & $15,4 \%$ & 102,3 & $4,3 \%$ \\
\hline Total & 3315,1 & 1211,6 & $36,5 \%$ & 618,1 & $18,6 \%$ & 843,7 & $25,5 \%$ & 454,5 & $13,7 \%$ & 187,2 & $5,6 \%$ \\
\hline
\end{tabular}

The analysis of the table shows that the North region is the largest consumer of diesel oil and electricity in the economic activities indicated. In the agricultural sector, the region demands $53 \%$ of all diesel oil, $78 \%$ of fuel oil and approximately $50 \%$ of all electric energy consumed in the whole state for that sector. This region is the largest grain producer in the state explains the high energy consumption in the agricultural sector.

The Mesoregion Centre-South is responsible for the consumption of $100 \%$ of fuel oil and $34 \%$ of diesel oil demanded in the industrial sector concerning the other regions of the state of MT. As previously mentioned, this region stands out among the different areas of the state due to the presence of several industries.

The Southeast mesoregion presents a well-distributed energy consumption of diesel oil and electricity in the evaluated economic sectors. Fuel oil consumption is practically nonexistent in this mesoregion, and the greater prominence refers to diesel oil used in the transport sector. The region is responsible for $30 \%$ of all consumption of the state in that sector.

The Southwest region, which stands out for its mineral activity, consumes more energy in the industrial sector. This region is responsible for demanding $20 \%$ of all the diesel oil in the state of MT used for industry. On the other hand, the consumption of fuel oil in the agricultural and industrial sectors is nonexistent. 
The Northeast is the region with the lowest energy consumption in the entire state of MT because it is the area with the greatest socio-economic disadvantage.

Data collection about the mesoregions' consumer market occurred to define in which cities the main agricultural and industrial consuming centers of fuel oil, diesel and electricity were located. This information served as a reference for choosing a centroid in each of the five mesoregions that could represent a centralized consumption point of the analyzed energy sources.

The average costs of fuel oil, diesel, and electric power in the state of MT were collected from the economic sectors studied.

Regarding the costs referring to fuel oil and diesel oil, the average values practiced in Brazil corresponds to R $\$ 286$ and $\mathrm{R} \$ 368$, respectively (MME, 2019c). Using the conversion factors for NG (Naval, 2009) and exchange rate conversions, the final prices for fuel oil and diesel oil correspond to 13.11 USD/MMBtu and 27.93 USD/MMBtu (MME, 2019c).

The electricity cost data applied to agriculture and industry were obtained from the Federation of Industries of the State of Rio de Janeiro (Firjan, 2017), and also transformed into USD/MMBtu through the same references cited in the previous paragraph for energy unit conversion and exchange rate conversion. Thus, the value of USD 27.93/MMBtu was obtained for the cost of electricity practiced in the MT.

The cost of NG imported from Bolivia corresponds to 7.766 USD/MMBtu (MME, 2019a). This value is formed by the sum of costs relative to the gas molecule and the transport costs in the Lateral-Cuiabá gas pipeline between Bolivia and the Cuiabá city-gate (MME, 2019a).

\section{RESULTS}

\subsection{Calculation of routes from the liquefaction plant to the consumer points}

Using the parameters described in the methodology, five routes were defined, which were calculated between the liquefaction plant of Cuiabá and the centroids of the mesoregions. The routes between the assumed liquefaction plant in Cuiabá city-gate and the centroids of the five areas of the state are demonstrated through lines in Figures 2 and 3.

\subsection{Calculation of the potential for substitution of diesel oil, fuel oil and electricity by NG in mesoregions}

By inserting the energy consumption data of the five mesoregions of the MT state (supplied in Table 2) and the percentage of substitution of electricity, diesel oil and fuel oil by NG in the Equations 1 to 4, described in the methodology, one obtains a theoretical potential volume of NG consumption in the agricultural, industrial and transport sectors in each of the five mesoregions of the state. As a result of this application, the theoretical aggregate demand was calculated at 2,083 MMm3/day.

Table 3 presents this volume segregated by the five mesoregions of the state of MT, the type of energy source for which NG has the potential of substitution and by the three economic activities evaluated.

As can be observed in Table 3, the North mesoregion, since it is the most developed region and the one that presents the largest energy consumption, emerges as the region that offers the largest NG consumption potential, corresponding to $0.93 \mathrm{MMm}^{3} /$ day (or $45 \%$ of the estimated 
theoretical potential demand). The Southeast Mesoregion presents the second-largest potential demand, responsible for $22 \%$ of the total estimated consumption for the state.

Table 3 - Total NG substitution potential in MT

\begin{tabular}{lllllllll}
\hline \multirow{2}{*}{ Mesoregion } & \multicolumn{2}{l}{ Replacement by Natural Gas $\left(\mathbf{m}^{\mathbf{3}} / \mathbf{d i a}\right)$} & & & & \\
\cline { 2 - 9 } & $\begin{array}{l}\text { Fuel Oil at } \\
\text { industry }\end{array}$ & $\begin{array}{l}\text { Diesel at } \\
\text { industry }\end{array}$ & $\begin{array}{l}\text { Electricity at } \\
\text { industry }\end{array}$ & $\begin{array}{l}\text { Diesel at } \\
\text { Transport }\end{array}$ & $\begin{array}{l}\text { Fuel Oil at } \\
\text { Agriculture }\end{array}$ & $\begin{array}{l}\text { Diesel at } \\
\text { Agriculture }\end{array}$ & $\begin{array}{l}\text { Electricity at } \\
\text { Agriculture }\end{array}$ & Total \\
\hline South & 5.031 & 15.007 & 45.664 & 128.467 & & 57.537 & 13.257 & 264.963 \\
Center & & 349 & 8.564 & 39.490 & - & 192.040 & 15.361 & 255.804 \\
Northeast & - & 14.745 & 62.676 & 151.670 & 3.458 & 615.548 & 83.750 & 931.847 \\
North & - & 4.799 & 51.581 & 149.092 & 943 & 215.244 & 41.244 & 462.903 \\
Southeast & - & 9.510 & 30.559 & 30.309 & - & 81.306 & 16.203 & 167.887 \\
Southwest & - & 44.410 & 199.044 & 499.028 & 4.401 & 1.161 .675 & 169.815 & 2.083 .404 \\
Total & 5.031 & & & & & &
\end{tabular}

The Mesoregions Center South and Northeast have both potential demands equivalent to $12 \%$ of the total estimated potential consumption for the state. However, the Northeast mesoregion presents the smallest potential consumption of NG in the entire state of MT to absorb $8 \%$ of the total identified demand.

\subsection{Design and calculation cost of liquefaction, storage and regasification plants}

Table 4 presents the estimated costs for LNG (in USD/MMBtu) for each mesoregion of MT state, obtained from the economic model and disaggregated values in liquefaction stages LNG transport and storage and regasification.

The distances to be covered are central to the definition of the competitiveness of NG. Thus, the LNG movement cost (excluding the NG cost) represents only $5 \%$ of the total logistic cost in the South-Central region. However, this percentage jumps to $27 \%$ for supplying the North Mesoregion, which presents more favorable replaceable energy sources.

\subsection{Calculation of the total cost of NG + Small-Scale LNG, comparison with other energy sources and georeferencing the results}

In step 5, the total costs of NG and LNG Logistics were calculated, considering the equation presented in the methodology. Table 4 shows the results obtained regarding the cost difference in the substitution of fuels by NG evaluated in this study (step 6).

Table 4 - Difference of costs between NG consumption in substitution of the other fuels studied

\begin{tabular}{|c|c|c|c|c|c|c|c|c|c|c|c|}
\hline \multirow{2}{*}{ Mesoregion } & \multicolumn{5}{|c|}{$\begin{array}{c}\text { Costs of NG + LNG Logistics } \\
\text { (USD/MMBTU) }\end{array}$} & \multicolumn{3}{|c|}{$\begin{array}{l}\text { Energetics Costs } \\
\text { (USD/MMBTU) }\end{array}$} & \multicolumn{3}{|c|}{$\begin{array}{c}\text { Cost Gap } \\
\text { (USD/MMBTU) }\end{array}$} \\
\hline & GN & Liquefaction & Transport & $\begin{array}{c}\text { Storage and } \\
\text { Regas. }\end{array}$ & $\begin{array}{c}\text { Total Cost } \\
\text { LNG Logistics }\end{array}$ & Electr. & $\begin{array}{c}\text { Diesel } \\
\text { Oil }\end{array}$ & $\begin{array}{c}\text { Fuel } \\
\text { Oil }\end{array}$ & $\begin{array}{l}\text { Electr. } \\
\text { - LNG }\end{array}$ & $\begin{array}{l}\text { Diesel Oil } \\
\text { - LNG }\end{array}$ & $\begin{array}{l}\text { Fuel Oil } \\
\text { - LNG }\end{array}$ \\
\hline South Center & 7,77 & 3,79 & 1,97 & 0,31 & 13,84 & 27,93 & 30,48 & 13,11 & 14,09 & 16,64 & $-0,73$ \\
\hline Northeast & 7,77 & 3,79 & 2,04 & 1,94 & 15,54 & 27,93 & 30,48 & n.a & 12,39 & 14,94 & n.a \\
\hline North & 7,77 & 3,79 & 0,61 & 1,63 & 13,80 & 27,93 & 30,48 & 13,11 & 14,13 & 16,68 & $-0,69$ \\
\hline Southeast & 7,77 & 3,79 & 1,15 & 0,67 & 13,38 & 27,93 & 30,48 & 13,11 & 14,55 & 17,10 & $-0,27$ \\
\hline Southwest & 7,77 & 3,79 & 3,07 & 1,63 & 16,26 & 27,93 & 30,48 & n.a & 11,67 & 14,22 & n.a \\
\hline Mean & 7,77 & 3,79 & 1,77 & 1,24 & 14,57 & 27,93 & 30,48 & 13,11 & 13,36 & 15,91 & $-1,46$ \\
\hline
\end{tabular}

Regarding electricity, it is possible to verify from Table 4 that the cost of delivering NG through LNG is lower than the cost of using electricity in industry and the agricultural sector in the five mesoregions of the state of MT. The average cost of electricity in MT corresponds to 
USD 28.0/MMBtu for industry and agriculture. In contrast, the average cost of using NG transported as LNG corresponds to USD 14.6/MMBtu in the same economic sectors. Therefore, NG's substitution in the agricultural and industrial sectors would result in an economy of 52\% for the final user of the two sectors evaluated.

In order to represent the cost discrepancy between NG use and electricity use, Figure 2 illustrates this cost difference in the five mesoregions evaluated, where the darker the mesoregion is, the larger is the difference between the costs of substituting electric energy by $\mathrm{NG}$ and, therefore, the greater is the competitiveness of this displacement.

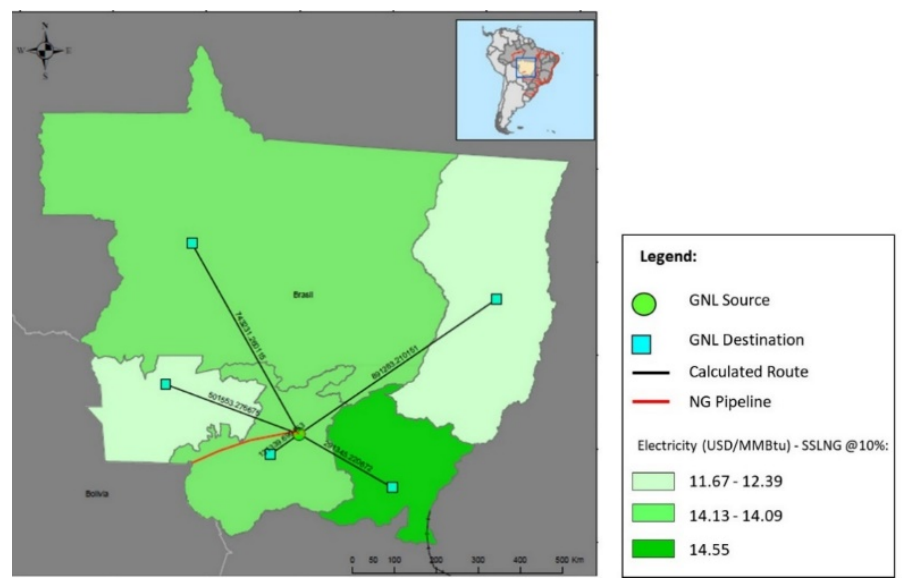

Figure 2. Intensity of cost differences between LNG and electricity between the mesoregions state of MT. Note: Image merely illustrative. The calculated routes considered the paved roads between the potential liquefaction plant (located in Cuiabá) and the five centroid points in each mesoregion for the simulation.

The Southeast Mesoregion, which stands out both for its agricultural and industrial activities, presents the largest cost difference in the state: 14.54 USD /MMBtu in favor of NG. The North mesoregion is responsible for consuming half of the electricity for the agriculture sector and is the largest consumer of this energy source in the industry makes the cost difference in substitution by NG slightly lower (14.15 USD/MMBtu) relative to the Southeast. Furthermore, the difference of distances between Cuiabá's city-gate and the centroids of the two mesoregions favored the Southeast's slight competitiveness compared to the North.

The cost difference in replacing it with NG was also positive in all five mesoregions of the MT state regarding diesel oil. The cost of diesel oil in the agriculture and husbandry, industrial and transport sectors corresponds to USD 30.5/MMBtu. The cost of NG consumption in the same activities is equivalent to an average value of USD 16.0/MMBtu in the five mesoregions. The substitution of diesel oil by NG would represent a $48 \%$ reduction of the energy cost in the three economic sectors of the state.

As it happens in the substitution of electricity by NG, the differences observed in the costs for the five mesoregions are similar when diesel oil is replaced by $\mathrm{NG}$, being differentiated by transport costs (mainly due to the distance between the liquefaction plant and the centroids of each mesoregion) and by storage and regasification costs that are directly proportional to the LNG transported volumes.

Again, the Southeast and North were the most competitive mesoregions of the state for the diesel replacement for NG, presenting a cost discrepancy of $17.1 \mathrm{USD} / \mathrm{MMBtu}$ for the Southeast and 16.7 USD/MMBTU North in favor of NG, which represents an economic of 
approximately 45\%. Figure 3 illustrates the cost differences observed in the 5 mesoregions of MT for this substitution.

Finally, the substitution of fuel oil by NG in the agricultural and industrial sectors shows that the cost of fuel oil is slightly lower than the cost of NG, corresponding to an average of USD 0.56/MMBtu in favor of fuel oil. The average price of fuel oil in the MT state, equivalent to 13.1 USD/MMBtu, is lower than the cost of NG transportation, via LNG to the MT state (14.6 USD/MMBtu). The Northeast and Southwest regions, due to the absence of fuel oil consumption in the Energy Balance of the MT state in their agricultural and industrial activities, were excluded from this comparison.

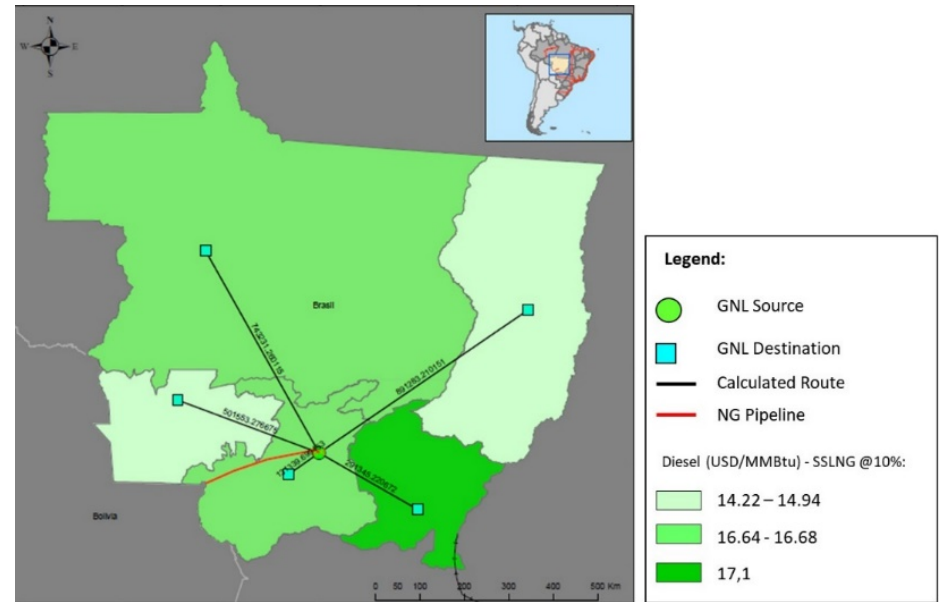

Figure 3. Intensity of cost differences between NG and diesel oil between the MT state mesoregions. Note: Image merely illustrative. The calculated routes considered the paved roads between the potential liquefaction plant (located in Cuiabá) and the five centroid points in each mesoregion for the simulation.

\section{CONCLUSION}

The GASBOL is one of the largest energy integration projects in the South American continent and a milestone in commercial and geopolitical relations between Brazil and Bolivia. The closeness to Bolivia and the availability of a pipeline connecting the two countries operating with high idleness are strong elements of the attractiveness of Bolivian NG in the state of MT, despite the absence of a robust pipeline network within the state. Besides the factors mentioned, the agricultural power present in MT, with a potential for growth in demand, is an additional motivator for developing the present simulation scenarios. It is an economic frontier region that presents economic wealth growth equivalent to that observed in the main emerging countries of the planet.

The use of a quantitative model for estimating LNG production and transport costs on a small-scale made it possible to obtain the total costs of LNG transport by truck and individualize for each one of the five mesoregions of the MT state. The simulation sought to compare it to the consumption costs of diesel, fuel oil and electricity used in agricultural, industrial, and transportation fields on those mesoregions. The estimation of these costs allows evaluating the competitiveness of Bolivian natural gas as an alternative to other energy sources consumed in the state.

The simulation identified a potential demand of $2.01 \mathrm{MMm}^{3} /$ day of $\mathrm{NG}$ and identified a 15 USD/MMBtu average cost to transport it by LNG to those five mesoregions of Mato Grosso state. 
The difference between the costs of using NG to replace electricity in agricultural and industrial sectors was USD 13/MMBtu average in favor of the NG. When the replacement of diesel by NG was assessed in the agricultural, industrial, and transportation sector, this paper showed a difference of 16 USD/MMBtu average also in favor of the NG.

In the simulation in which NG replaces fuel oil in agricultural and industrial sectors, the difference cost between the two energy sources was irrelevant. The cost of fuel oil consumption was slightly lower than the cost of using NG transported via LNG. (0.56 USD/MMBtu in favor of fuel oil).

The study has some limitations, such as the assumption, for simulation purposes, that the centroids of the mesoregions concentrate all of the state's energy consumption for the agricultural, industrial, and transportation sectors. Although this premise contributes to the initial evaluation of the substitution of some fossil fuels for natural gas, the authors suggest that, for future studies, the identification of specific consumption points throughout the state of MT, so that, in the simulation, each point receives the volume necessary for its demand.

Although more sophisticated models need to be elaborated, the results presented here show, without question, the competitiveness of LNG in all the mesoregions of the MT state. It can be verified that the combination of a larger NG consumption potential and a smaller distance relative to Cuiabá's city-gate allows lower logistic costs for LNG and even larger gains for local consumers in energy strategies with a larger participation of Bolivian NG. As a matter of fact, this result is not completely surprising since such a situation replicates what is already observed regarding the greater competitiveness of Bolivian NG in the markets served by GASBOL in the South and Southeast regions of Brazil.

With regard to sustainability aspects, despite not being the focus of this study, the competitiveness of LNG with diesel and oil found in the simulation indicates the potential of LNG to reduce carbon emissions without increasing costs for the sectors studied. However, to understand the implication of these results for the reduction of GHG emissions, other aspects need to be analyzed, such as the emissions of the trucks (possibly powered with diesel fuel) transporting LNG from the Cuiabá city-gate to the consumption sites. Thus, research focused on this issue needs to be conducted to compare the carbon footprint of this energy source change with the current ones.

The prospect of economic growth in any nation is directly related to an energy supply to support the transportation and production sectors. In this sense, South America has an abundance and diversity of energy resources. Both Bolivia and Brazil have a privileged geographical location for a broad energy integration in the continent, considering alternatives means of transportation.

\section{ACKNOWLEDGEMENTS}

The authors gratefully acknowledge support of the 'Research Centre for Gas Innovation - RCGI' (FAPESP Proc. 2014/50279-4), hosted by the University of São Paulo, and the strategic importance of the support given by ANP (Brazil's National Oil, Natural Gas and Biofuels Agency) through the R\&D levy regulation. Anna Luisa Netto thanks Capes. Drielli Peyerl thanks especially the current financial support of grant Process 2017/18208-8 and 2018/26388-9, São Paulo Research Foundation (FAPESP).

\section{REFERENCES}

Alam, Md. S.; Paramati, S. R.; Shahbaz, M. and Bhattacharya, M. (2017) Natural gas, trade and sustainable growth: empirical evidence from the top gas consumers of the developing world. Applied Economics, v. 49, n. 7, p. 635-649. DOI: $10.1080 / 00036846.2016 .1203064$ 
Alexopoulos, T. A. (2017). The growing importance of natural gas as a predictor for retail electricity prices in US. Energy, v. 137, p. 219-233. DOI: 10.1016/j.energy.2017.07.002

Alves, L. M., Domingues, A., and Carvalho, M. da G. (2005) Small scale LNG in Madeira Island. Available at: <https://inis.iaea.org/search/search.aspx?orig_q=RN:40022830> (access in 23/03/2020).

ANP. (2019). Boletim da Produção de Petróleo e Gás Natural (Issue 102). Available at: <http://www.anp.gov.br/arquivos/publicacoes/boletins-anp/producao/boletim-fevereiro-2019.pdf> (access in $15 / 05 / 2020)$

Azevedo Filho, E. T.; Palma, M. A. M.; Perestrelo, M.; da Hora, H. R. M. and Lira, R. A. (2019). The pre-salt layer and challenges to competitiveness in Brazil: Critical reflections on the local content policy in the oil and gas Sector. The Extractive Industries and Society, v. 6, n. 4, p. 1168-1173. DOI: 10.1016/j.exis.2019.09.009

BCB. (n.d.). Séries de estatísticas consolidadas. Available at: <https://www3.bcb.gov.br/expectativas/publico/consulta/serieestatisticas> (access in 08/11/2018)

Biscardini, G., Schmmill, R. and Maestro, A. (2017) Small going big: Why small-scale LNG may be the next big wave. Available at: <https://www.strategyand.pwc.com/gx/en/insights/2017/small-going-big.html> (access in 30/06/2019).

Bittante, A., Pettersson, F. and Saxén, H. (2018). Optimization of a small-scale LNG supply chain. Energy, v. 148, p. 79-89. DOI: 10.1016/j.energy.2018.01.120

BP. (2019). British Petroleum Statistical Review of World Energy. Available at: <https://www.bp.com/content/dam/bp/business-sites/en/global/corporate/pdfs/energy-economics/statisticalreview/bp-stats-review-2019-full-report.pdf> (access in 09/11/2020).

Cathles, L. M. (2012). Assessing the greenhouse impact of natural gas. Geochemistry, Geophysics, Geosystems, v. 13, n. 6, p. 1-38. DOI: $10.1029 / 2012 \mathrm{GC} 004032$

Cavalcante, M. C. B. (2004). Ascenção do gás natural no mercado de combustíveis automotivos no Brasil. $3^{\circ}$ Congresso Brasileiro de P\&D Em Patróleo e Gás. Natal: ABPG, p. 1-5.

Cezário, W. R.; Antunes, A. M. de S.,;Leite, L. F. and Menezes, R. P. B. de. (2015). The energy revolution in the USA and the presalt reserves in Brazil: Risks and opportunities for the Brazilian petrochemical industry. Futures, v. 73, p. 1-11. DOI: 10.1016/j.futures.2015.07.013

Colombo, S., El Harrack, M. and Sartori, N. (2016). The Future of Natural Gas Markets and Geopolitics. The Netherlands: Lenthe/European Energy Review.

Costa, I. V. L. da; Rochedo, P.; Império, M.; Szklo, A. S. and Schaeffer, R. (2016). Production in Offshore Reservoirs in Brazil's Pre-salt Region. In P. Grammelis (Ed.), Energy, Transportation and Global Warming. Springer International Publishing. (p. 617-629). DOI: 10.1007/978-3-319-30127-3

DNPM. (2017). Anuário Mineral Brasileiro - Principais Substâncias Metálicas. Available at: <https://www.gov.br/anm/pt$\mathrm{br} /$ centrais-de-conteudo/publicacoes/serie-estatisticas-e-economia-mineral/anuario-mineral/anuario-mineralbrasileiro/amb_metalicos2017> (access in 21/03/2019)

dos Santos, E. M. (2002). Gás natural: estratégias para uma energia nova no Brasil. São Paulo: Annablume.

EPE. (2019). Balanço Energético Nacional 2019 - Relatório Síntese / Ano Base 2018. Available at: $<$ https://www.epe.gov.br/pt/publicacoes-dados-abertos/publicacoes/balanco-energetico-nacional-2019> (access in $03 / 02 / 2020)$

Firjan. (2017). Quanto custa a energia elétrica para a pequena e média indústria no Brasil? <https://www.solrico.com/fileadmin/solrico/media/doc/pdf_presentations/sistema-firjan-2016.pdf> (access in 19/10/2019)

Fraga, D. M. (2019). A movimentação de gás natural comprimido e liquefeito em pequena escala: as fronteiras de competitividade do modal rodoviário. Instituto de Energia e Ambiente, Universidade de São Paulo. São Paulo. DOI: 10.11606/D.106.2019.tde-19122018-092510

Fraga, D. M.; Liaw, C. and Gallo, A. de B. (2017). Techninal visits to LNG Import Terminals from ENAGAS at Cartagena in Spain and from REN Atlantico, at Sines in Portugal.

Gallo, A. de B. (2018). Avaliação da inserção do gás natural no setor industrial brasileiro: uma análise de indicadores de impactos energético, ambiental e econômico. Instituto de Energia e Ambiente, Universidade de São Paulo. DOI: 10.11606/D.106.2018.tde-09042018-173952

García Kerdan, I.; Jalil-Vega, F.; Toole, J.; Gulati, S.; Giarola, S. and Hawkes, A. (2019). Modelling cost-effective pathways for natural gas infrastructure: A southern Brazil case study. Applied Energy, 255, 113799. DOI: 10.1016/j.apenergy.2019.113799

Hekkert, M. P.; Hendriks, F. H. J. F.; Faaij, A. P. C. and Neelis, M. L. (2005). Natural gas as an alternative to crude oil in automotive fuel chains well-to-wheel analysis and transition strategy development. Energy Policy, v. 33, n. 5, p. 579-594. DOI: 10.1016/j.enpol.2003.08.018

Hondo, H. (2005). Life cycle GHG emission analysis of power generation systems: Japanese case. Energy, v. 30, n. 11-12, p. 2042-2056. DOI: 10.1016/j.energy.2004.07.020

Howarth, R. W. (2014). A bridge to nowhere: methane emissions and the greenhouse gas footprint of natural gas. Energy Science \& Engineering, v. 2, n. 2, p. 47-60. DOI: 10.1002/ese3.35

IBGE. (2019). Panorama Mato Grosso. Available at: <https://cidades.ibge.gov.br/brasil/mt/panorama> (access in $30 / 11 / 2019)$. 
IGU. (2015). Small Scale LNG: 2012-2015 Triennium Work Report. Available at: <https://www.igu.org/news/igu-world-lngreport-2015-edition/> (access in 13/04/2019)

IMEA. (2019). Agronegócio no Brasil e em Mato Grosso. Available at: <https://www.imea.com.br/imeasite/view/uploads/relatorios-mercado/Apresentacao_20190426.pdf> (access in 12/04/2019)

Kumar, S., Kwon, H.-T., Choi, K.-H., Lim, W., Cho, J. H., Tak, K. and Moon, I. (2011). LNG: An eco-friendly cryogenic fuel for sustainable development. Applied Energy, v. 88, n. 12, p. 4264-4273. DOI: 10.1016/j.apenergy.2011.06.035

Levi, M. (2013). Climate consequences of natural gas as a bridge fuel. Climatic Change, v. 118, n. 3-4, p. 609-623. DOI: $10.1007 / \mathrm{s} 10584-012-0658-3$

Liaw, C. (2019). Novas fronteiras de expansão para o gás natural: o suprimento em pequena escala através da malha ferroviária brasileira. Instituto de Energia e Ambiente, Universidade de São Paulo. São Paulo. DOI: 10.11606/D.106.2019.tde19122018-113127

Matsubara, E. (2016). Release do setor secundário de Mato Grosso. Available at: <http://www.procon.mt.gov.br/documents/363424/3008377/RELEASE+DO+SETOR+SECUND\%C3\%81RIO+DE+MATO+ GROSSO/3f00b378-7e1c-4bbe-878a-4383dfb412a2> (access in 12/04/2019)

MME. (2019a). Boletim Mensal de Acompanhamento da Indústria do Gás Natural (2009-2019). <http://www.mme.gov.br/web/guest/secretarias/petroleo-gas-natural-e-combustiveis-renovaveis/publicacoes/boletimmensal-de-acompanhamento-da-industria-de-gas-natural> (access in 05/12/2019)

MME. (2019b). Novo mercado de Gás. Available at: <http://www.mme.gov.br/web/guest/conselhos-e-comites/cmgn/novomercado-de-gas> (access in 05/05/2019)

MME. (2019c). Relatório do Mercado de Derivados de Petróleo. Available at: <http://antigo.mme.gov.br/web/guest/secretarias/petroleo-gas-natural-e-biocombustiveis/publicacoes/relatoriomensal-do-mercado-de-derivados-de-petroleo> (access in 06/09/2019)

Mokhatab, S.; Mak, J. Y.; Valappil, J. V. and Wood, D. A. (2014). Handbook of Liquefied Natural Gas. Amsterdam: Elsevier.

Mouette, D.; Machado, P. G.; Fraga, D.; Peyerl, D.; Borges, R. R.; Brito, T. L. F.; Shimomaebara, L. A. and dos Santos, E. M. (2019). Costs and emissions assessment of a Blue Corridor in a Brazilian reality: The use of liquefied natural gas in the transport sector. Science of The Total Environment, v. 668, p. 1104-1116. DOI: 10.1016/j.scitotenv.2019.02.255

Naval, P. (2009). Tabelas de Conversão de Petróleo e Gás. Available at: <http://www.portalnaval.com.br/media/tabela/conversao_petroleo_gas_1.pdf> (access in 08/04/2019).

NIEPE. (2017). Balanço energético do Estado do Mato Grosso e Mesorregiões. Available at: < http://www.sedec.mt.gov.br/documents/195466/2296326/Balan\%C3\%A7o+Energ\%C3\%A9tico+do+Estado+de+MT+2 015.pdf/eb0fc280-c58b-4dde-8554-13e44594ac5c> (access in 21/05/2019)

Openstreetmap. (2018). Malha rodoviária do openstreetmap. Available at: <http://www.openstreetmap.com.br/> (access in 04/02/2019)

Safari, A.; Das, N.; Langhelle, O.; Roy, J. and Assadi, M. (2019). Natural gas: A transition fuel for sustainable energy system transformation? Energy Science \& Engineering, v. 7, n. 4, p. 1075-1094. DOI: 10.1002/ese3.380

Santos, E. M. dos; Fagá, M. T. W.; Barufi, C. B. and Poulallion, P. L. (2007). Gás natural: a construção de uma nova civilização. Estudos Avançados, v. 21, n. 59, p. 67-90. DOI: 10.1590/S0103-40142007000100007

Teixeira, J. P. B. (2015). Gás Natural: O energético mais competititvo. Rio de Janeiro: PoD.

Zhang, X.; Myhrvold, N. P.; Hausfather, Z. and Caldeira, K. (2016). Climate benefits of natural gas as a bridge fuel and potential delay of near-zero energy systems. Applied Energy, v. 167, p. 317-322. DOI: 10.1016/j.apenergy.2015.10.016

'Gallo (2018) and Strapassono (2004), in their respective papers, consider the percentages of electricity and diesel oil substitution for the following types of industry:

- Food and Beverage): 30\% - Non Metallic Minerals): 30\%

- Iron and Steel): $27 \%$ - Paper and Pulp): $2 \%$

- Mining): 38\% - Non-Ferrous Metals: $37 \%$

- Chemical): $36 \%$ - Textile: $22 \%$

- Industry Average: 28\% 